\title{
Exclusionary Zoning in California: A Statutory Mechanism for Judicial Nondeference
}

The principal authority for land-use regulation in Cahifornia, in accord with the national pattern, ${ }^{1}$ has been delegated by the State to local governments. ${ }^{2}$ Many localities have utilized this delegation to promote "exclusionary" residential patterns through the impleinentation of restrictive zoning ordinances. Minimum lot size requirements, restrictions, or outright prohibitions on multifamily residential dwellings, prohibitively expensive building code standards, and other exclusionary zoning techniques have both adversely impacted the metropolitan housing inarket ${ }^{3}$ and accelerated the decline of tax bases of central cities. Moreover, exclusionary zoning has fostered continued socioeconomic and racial segregation. ${ }^{4}$ The proliferation of exclusionary zoning ordimances, particularly in California, is a formidable trend in contemporary land-use regulation requiring contimuing public scrutimy.

Since zoning was first upheld as a legitimate exercise of the state's police power, ${ }^{5}$ however, the courts liave been reluctant to invalidate local zoning ordinances. Judicial deference to the local zoning process has been prompted by two concerns: first, that the courts lack the requisite expertise to review zoning decisions, ${ }^{6}$ and second, that zoning is a political decision regarding socioeconomic regulation with which

1. D. Hagman, Urban Planning and Land Development Control Law 76 (1971).

2. CAL. Const. art. XI, \& 7; CAL. Gov'T CODE $\S \S 65800-65803$ (West Supp. 1977).

3. Developments in the Law-Zoning, 91 HARv. L. REv. 1427, 1624-32 (1978).

4. This Comment does not attempt to fully analyze the social problems inherent in exclusionary zoning. For more detailed analyses, see R. BABCOCK \& F. BOSSELMAN, EXClusionarY ZoNing: LaNd Use Regulation and Housing iN THE 1970s (1973); Ellickson, Suburban Growth Controls: An Economic and Legal Analysis, 86 YALE L.J. 385 (1977); Sager, Tight Little Islands: Exclusionary Zoning, Equal Protection and the Indigent, 21 STAN. L. Rev. 767 (1969); Williams \& Doughty, Studies in Legal Realism: Mt. Laurel, Belle Terre and Berman, 29 RuTGERS L. Rev. 73 (1975); Symposium-Exclusionary Zoning, 22 SYRACUSE L. REv. 465 (1971).

5. Village of Euclid v. Ambler Realty Co., 272 U.S. 365 (1926); Miller v. Board of Pub. Works, 195 Cal. 477, 234 P. 381 (1925). In addition to Euclid, the United States Supreme Court has considered only five zoning cases, and has upheld the general zoning scheme in each case. Village of Arlington Heights v. Metropolitan Hous. Dev. Corp., 429 U.S. 252 (1977); Young v. American Mini Theatres, Inc., 427 U.S. 50 (1976); City of Eastlake v. Forest City Enterprises, lnc., 426 U.S. 668 (1976); Warth v. Seldin, 422 U.S. 490 (1975); Village of Belle Terre v. Boraas, 416 U.S. 1 (1974); Nectow v. City of Cambridge, 277 U.S. 183 (1928).

6. Note, Judicial Limitations on Local Growth Controls: Regional Needs as an Elentent of the “General Welfare," 66 CALIF. L. Rev. 373, 379 (1978). 
courts should not interfere. ${ }^{7}$ Consequently, the deferential standard of minimum rationality has traditionally been apphed by the courts in zoning challenges, striking down the ordinance only if its provisions bore no significant relationship to the "general welfare" of the particular community. ${ }^{8}$

In a recent developinent, soine state courts have becoine progressively dissatisfied with the deferential standard of judicial review im the exclusionary zoning context. Probably the most significant attempt to formulate a new standard of review was the New Jersey Supreme Court's decision in Southern Burlington County NAACP v. Township of Mt. Laurel, ${ }^{9}$ which required a suburban community to provide adequate housing for a judicially determmed percentage of the region's low-inconie population. Although Mt. Laurel and comparable New York $^{10}$ and Peimsylvania ${ }^{11}$ decisions have been praised for initiatimg the denise of the deferential standard of judicial review, ${ }^{12}$ critics have questioned the competence of the judiciary to establish and enforce substantive rules in this highly complex area of socioeconomic regulation. ${ }^{13}$

The California Supreme Court recently addressed this issue in $A s$ sociated Home Builders v. City of Livermore. ${ }^{14}$ The court in Livermore unambivalently disposed of the deference standard by adopting a test which assessed whether a challenged local act represents a "reasonable accommodation of the competing interests." 15 The court did not resolve, however, the degree to which trial courts must defer to the defendant city's judgment that its accommodation is reasonable. This aunbiguity is apparently a manifestation of the conventional concern regarding judicial expertise in the zoning process. ${ }^{16}$ Thus, Livermore itself is better characterized as the decline of a prior standard rather than the creation of a new, concrete model for judicial review of exclusionary zoning practices in California.

A variety of Cahfornia statutes require that local land-use controls

7. See, e.g., United States v. Carolene Products Co., 304 U.S. 144, 154 (1938).

8. Village of Euclid v. Ambler Realty Co., 272 U.S. 365, 395 (1926).

9. 67 N.J. 151,336 A.2d 713 (1975). (1975).

10. Berenson v. Town of New Castle, 38 N.Y.2d 102, 341 N.E.2d 236, 378 N.Y.S.2d 672

11. Surrick v. Zoning Hearing Bd. of Upper Providence Township, $476 \mathrm{~Pa}$. 182, 382 A.2d 105 (1977); In re Kit-Mar Builders, Inc., 439 Pa. 466, 268 A.2d 765 (1970); In re Girsh, 437 Pa. 237, 263 A.2d 395 (1970); National Land \& Inv. Co. v. Kohn, 419 Pa. 504, 215 A.2d 597 (1965).

12. See, e.g., Williams \& Doughty, supra note 4.

13. See, e.g., Payne, Delegation Doctrine in the Reform of Local Government Law: The Case of Exclusionary Zoning, 29 RUTGERS L. REv. 803 (1976).

14. 18 Cal. 3d 582, 557 P.2d 473, 135 Cal. Rptr. 41 (1976).

15. Id. at 609,557 P.2d at 488,135 Cal. Rptr. at 56.

16. See text accompanying notes $22-29$ infra. 
be consistent with a general plan that must provide for the housing needs of "all economic segments of the community."17 These statutes are enforced on a statewide basis by regulations, promulgated by the California Department of Housing and Community Development, which quite specifically identify the housing obligations of each locality subject to a general plan. ${ }^{18}$ Numerous questions remain unresolved under this approach, including: (a) the scope of interests intended to be protected under the rubric "community;" (b) whether the regulations promulgated under this statute are binding or advisory; (c) whether this statutory scheme applies to charter municipalities; and (d) the appropriate form of judicial action to enforce these mandates. Nevertheless, this Cominent will argue that California statutes currently im effect create a sufficient mechanism for the formulation of substantive judicial standards to evaluate zoning ordinances with exclusionary effects.

Part I of this Comment will analyze the traditional doctrine of selfrestraint which courts have applied im challenges to zoning ordmances, arguing that the policies underlying the doctrine are not applicable when ordniances have impacts extending beyond municipal boundaries. Part II will discuss the institutional problems faced by a court attempting to review zoning ordinances with external impacts. In response to the problems identified in Parts I and II, Part III will analyze Califormia's statutory and admimistrative structure concerning the related tasks of housing and zoning. It will conclude that these structures have created a meaningful framework for judicial review, and that public policies for the provision of low- and moderate-income housing developed by both the legislature and state agencies will be more effectively facilitatcd by the activist judicial role sanctioned in the Livermore decision.

\section{REGIONAL ZONING REPERCUSSIONS AND JUDICIAL DEFERENCE}

In 1925, the Califormia Supreme Court upheld zoning as a legitimate exercise of the police power. ${ }^{19}$ The United States Supreme Court reached the same result one year later. ${ }^{20}$ It has since become apparent that courts will not invalidate zoning ordinances if any substantial reason exists to support the decision of the local authorities. ${ }^{21}$ If the ordi-

17. CAL. Gov't CODE § 65302(c) (West Supp. 1978).

18. Id.

19. Miller v. Board of Pub. Works, 195 Cal. 477, 234 P. 381 (1925).

20. Village of Euclid v. Ambler Realty Co., 272 U.S. 365 (1926).

21. Associated Home Builders, Inc. v. City of Livermore, 18 Cal. 3d 582, 604-05, 557 P.2d 473, 485-86, 135 Cal. Rptr. 41, 53-54 (1976). Cleanlimess and beauty, as well as health and safety, 
nance has a minimum rational basis, the court will not consider whether less exclusionary alternatives are available, or whether the purported rationale is actually the motivation for the ordinance. No judicial interference will be permitted as long as "reasonable minds might differ." 22

When the effect of a zoning ordinance will not extend beyond the city limits, this doctrine of judicial deference to local government has great appeal. Courts still heed the lessons of the Lochner era, ${ }^{23}$ when judges used concepts of substantive due process to substitute their views on socioeconomic regulation for those of the elected legislature. If state appellate judges ultimately determined the vahidity of zoning ordinances exclusively affecting the enacting inunicipality, the benefits of local land-use decisionmaking would be impaired. These state judges are either appointed or elected on a regional basis and, consequently, lack pohtical responsiveness to local planning needs on the inunicipal level. Additionally, judges inay be unable to adequately assess the underlying social and economic inunicipal tensions that must be balanced im designing a local zoning scheme.

The proliferation of satellite cominunities and concomitant urban sprawl has created an interdependent network of zoned California communities. ${ }^{24}$ As a consequence of this interdependence, many local zoning ordinances have significant effects beyond the city limits of the enacting municipahty. Typically, an exclusionary zoning ordmance will affect the housing supply of an entire inetropolitan region. Real estate and rental inarkets of restrictive communities will be inaccessible to prospective low- and moderate-incoine residents, while other less restrictive locahties will necessarily be compelled to absorb a disproportionate sliare of this sector of the population. The organic regional housing inarket is distorted by the restrictive pohicies of any one of its coniponent units.

It is therefore apparent that the pohcies supporting the deference

have been deemed legitimate ends of the police power. Berman v. Parker, 348 U.S. 26, 32-33 (1954).

22. Clemons v. City of Los Angeles, 36 Cal. 2d 95, 98, 222 P.2d 439, 441 (1950).

23. Lochner v. New York, 198 U.S. 45 (1905). See generally L. TRIBE, AMERICAN ConSTITUTIONAL LAW 427-55 (1978). The description of the "Lochner era" has been commonly used in two related but distimct fashions. The era is known generally for the use of judicial power, under the doctrine of substantive due process, to strike down statutes which were socially or politically repugnant to the judges. It is in this sense that the term is used liere. The era is also known more specifically for the judicial recognition of profitmaking as an interest deserving of active judicial protection. See note 54 infra.

24. See generally National Comm'N on Urban Problems, Building the American City, H.R. Doc. No. 91-34, 91st Cong., Ist Sess. 211-16 (1969); Office of Planning ANd RESEARCh, AN URban STRATEgy for California 8 (1978); W. SMith, URban Development: The Process AND the Problems 363-68 (1975). 
standard do not apply to zoning ordinances with obvious regional repercussions. Although a city council is qualified to assess the needs of its residents, it may be unable or unwilling to gauge the effect of its ordinance in other parts of a inetropohtan region. Additionally, a local government faces an inherent conflict of interest in trying to weigh the benefits to its residents against the potential costs to other residents of the region. The judiciary's legitimate desire to defer to a more politically responsive agency is less compelling when zoning decisions affect regional residents who are unrepresented in the neighborhood zoning process.

Both the California legislature and the Cahifornia courts have begun to recognize that local governments cannot adequately consider regional interests in making certain land-use decisions. Legislation has specifically himited local decisionmakmg in the areas of resource allocation and conservation. One Cahfornia statute requires that, until the local government has devised a coastal development plan acceptable to the state commission, any developinent within a legislatively adopted coastal zone must be approved by a regional or state coastal commission. ${ }^{25}$ Certain land-use decisions affecting the San Francisco Bay or Lake Tahoe inust be approved by regional agencies. ${ }^{26}$ These acts reflect a concern that additional regional or state controls are necessary to protect resources and prevent excessive development. ${ }^{27}$ Similarly, the legislature has given a state agency exclusive control over the location of power plant facilities. ${ }^{28}$ This preemption of local control is based in part on a legislative finding that an orderly supply of energy needs requires expanded state authority. ${ }^{29}$

The California courts have independently recognized that probleins inay result from land-use decisions with regional consequences made solely by local agencies. In these situations, courts are ostensibly in a relatively less biased position than the adopting municipality to assess and balance competing interests in land-use policy.

For example, in Scott $v$. City of Indian Wells, ${ }^{30}$ the California

25. Cal. Pub. Res. Code $\S 30600$ (West 1977). For an analysis of the Coastal Act, see Review of Selectcd 1976 California Legislation-Environmental Protection, 8 PAC. L.J. 351 (1977).

26. CAL. Gov't Code $\S 66632$ (West Supp. 1979) (San Francisco Bay Conservation and Development Commission); Id. §66801 (Tahoe Regional Planning Agency).

27. CEEED v. California Coastal Zone Conservation Comm'n, 43 Cal. App. 3d 306, 322, 118 Cal. Rptr. 315, 326-27 (4th Dist. 1974). Of course, developers must still obtain approval from the local government, and local agencies may enact more stringent requirements than the regional or statewide agencies. CAL. Gov'T CODE $\S \S 66632$ (b), 66801 art. VI(a) (West Supp. 1977); CAL. PUB. RES. CODE $\$ 30600$ (a) (West 1977).

28. CAL. Pub. Res. CODE $\S 25500$ (West 1977). The Coastal Cominission also plays a role in siting of energy facilities within the Coastal Zone. Id. $\$ \S 25526,30413(b)$.

29. Id. $\$ 25005$.

30. 6 Cal. 3d 541, 492 P.2d 1137, 99 Cal. Rptr. 745 (1972). See Note, Judicial Linitations on 
Supreme Court held that due process requires a locality to consider the effects of proposed zoning amendinents on affected property owners living immediately outside city limits. In upholding the validity of regional land-use controls in Lake Talioe, the court observed that the unwillingness of the local governments to "subordinate sectarian economic interests in rapid growth and developinent of the lake basin to the national interest in preserving the lake as a national resource" resulted in madequate regulation. ${ }^{31}$ The court found the statewide concerns in preservation of the lake justified regional land-use restrictions despite the "home rule" provision of the Cahfornia Constitution. ${ }^{32}$ In dismissing a similar cliallenge to the Coastal Zone Conservation Act of 1972,33 a court of appeal noted that resolution of the competing demands upon slioreline land use "has proven to be beyond the capabilities of local governmental agencies."34

In Associated Home Builders v. City of Livermore, ${ }^{35}$ the Cahifornia Supreine Court recently indicated a willingness to increase judicial supervision of exclusionary land-use regulations with regional repercussions. Faced witl a challenge to a moratorium on building permits, ${ }^{36}$ the Court reaffirmed the "established constitutional principle" that a challenged ordmance will be upheld if it is "reasonably related to the public welfare." ${ }^{37}$ Proceeding to inquire "whose welfare inust the ordinance serve," 38 the court concluded that if an ordinance "inay strongly imfluence . . . an entire inetropolitan region, judicial inquiry must consider the welfare of that region." 39

Parochialism in Municipal Land Use Decisions: Scott v. City of Indian Wells, 25 HaStings L.J. 739 (1974).

31. Younger v. County of El Dorado, 5 Cal. 3d 480, 494 n.16, 487 P.2d I193, 1201 n.16, 96 Cal. Rptr. 553, 561 n.16 (1971) (quoting Comment, Lake Tahoe: The Future of a National AssetLand, Use, Water, and Pollution, 52 CALIF. L. Rev. 563, 618 (1964)).

32. 5 Cal. $3 d$ at 498,487 P.2d at 1204, 96 Cal. Rptr. at 564. See CAL. Const. art. XI, § 5. See also Sato, "Municipal Affairs" in California, 60 CALIF. L. Rev. 1055 (1972).

33. Cal. Pub. Res. Code $\$ \S 2700-27650$ (West 1977). The Act, adopted by initiative in 1972, expired in 1976 and was replaced by the California Coastal Act of 1976. CAL. PuB. Res. CODE $\S \S 30000-30900$ (West 1977).

34. CEEED v. California Coastal Zone Conservation Comm'n, 43 Cal. App. 3d 306, 322, 118 Cal. Rptr. 315, 326 (4th Dist. 1974). Courts have also upheld regional or state intervention, based on interests extending beyond a city's boundaries, in the areas of local agency formation, Simi Valley Recreation \& Park Dist. v. Local Agency Formation Comm'n, 51 Cal. App. 3d 648, 124 Cal. Rptr. 635 (2d Dist. 1975), and rehabilitation of the handicapped, City of Los Angeles v. California Dep't of Health, 63 Cal. App. 3d 473, 133 Cal. Rptr. 771 (2d Dist. 1976).

35. 18 Cal. 3d 582, 557 P.2d 473, 135 Cal. Rptr. 41 (1976).

36. The city had adopted an initiative ordinance banning the issuance of new building permits until local educational, sewage disposal, and water supply facilities complied with specified standards. Id. at 590, 557 P.2d at 477,135 Cal. Rptr. at 44 .

37. Id. at 607,557 P.2d at 487,135 Cal. Rptr. at 55 .

38. Id. (einphasis in original).

39. Id. 
In reaching this decision, the Livermore court emphasized that the zoning power is part of the State's police power delegated to the localities by the State. ${ }^{40}$ Althougl it is inconclusive on certain procedural questions, Livermore is an important first step in developing a new California standard for review of ordinances with regional repercussions. ${ }^{41}$

II

\section{REgIONAL ZONING REPERCUSSIONS AND NONDEFERENTIAL JUdICIAL SCRUTINY}

\section{A. State Courts and Nondeferential Scrutiny}

State courts liave assumed botll activist and deferential postures on the issue of local land-use regulation. Althougl Livermore lias freed California courts from traditional notions of deference, the scope of judicial competence in this area of socioeconomic regulation remains undefined. Two prominent state courts liave provided useful guidelines which the California judiciary would be well-advised to heed in the post-Livermore era.

In Southern Burlington County NAACP v. Township of Mt. Lau$\mathrm{rel}^{42}$ the New Jersey Supreine Court invalidated a local zoning ordinance that inade low- and moderate-cost lousing economically unfeasible within the city. The court based its decision on the theory that localities are delegated the zoning power froin the State and ac-

40. Id. at 608,557 P. $2 \mathrm{~d}$ at 488,135 Cal. Rptr. at 56 (citing Southern Burlington County NAACP v. Township of Mt. Laurel, 67 N.J. 151, 177, 336 A.2d 713, 726 (1975)). For a discussion of Mt. Laurel, see text accoinpanying notes $42-46$ infra.

41. There are two other rationales urging courts to extend nondeferential scrutiny to exclusionary zoning ordinances. The plaintiffs in Livermore asserted that thcir constitutional right to travel was harmed by the ordinance and judicial intervention was warranted to protect this right. The court rejected this argument. Citing Village of Belle Terre v. Boraas, 416 U.S. 1 (1974), with approval, the court held that the constitutional right to travel does not apply to legislation that makes it more difficult for an individual to establish residency in a given locality. Associated Hoine Builders v. City of Livermore, 18 Cal. 3d 582, 607, 557 P.2d 473, 484, 135 Cal. Rptr. 41, 52 (1976).

Although the plaintiffs in Livermore specifically did not press an equal protection argunent, id. at 602,557 P.2d at 484,135 Cal. Rptr. at 52 , such a challenge is conceivable, although unlikely to be successful under federal constitutional doctrine. Ybarra v. City of Los Altos Hills, 503 F.2d 250, 253-54 (9th Cir. 1974). Califormia, however, has rccently indicated that it would extend greater protection under the independent equal protection provisions of the state constitution than might be afforded under the fourteenth amendinent to the federal constitution. Scrrano v. Priest, 18 Cal. 3d 728, 557 P.2d 929, 135 Cal. Rptr. 345 (1976). Serrano indicates that wealth may be regarded as a suspect classification. Id. at 765-66, 557 P.2d at 951, 135 Cal. Rptr. at 367. Lowincome plaintiffs might be able to invoke nondeferential scrutiny of exclusionary zoning ordinances on this basis. Serrano also indicates that, unlike federal doctrine, it will invoke nondeferential scrutiny to protect "fundamental" interests which are not necessarily found in the state constitution. Id. at 767-68, 557 P.2d at 952, 135 Cal. Rptr. at 368. Plaintiffs inight be able to convince the court that housing is a fundamental interest deserving of judicial protection.

42. 67 N.J. 151,336 A.2d 713 (1975). 
cordingly must consider the welfare of all the State's residents who may be significantly affected by the regulation. ${ }^{43}$ The New Jersey court went on to declare that "proper provision for adequate housing for all [economic] categories of people is certainly an absolute essential in proinotion of the general welfare required in all local land use regulation."44 Accordingly, developing inunicipahties in New Jersey are required to zone land to provide a judicially mandated "fair share" of the regional housing need. ${ }^{45}$

Neglected in the Mt. Laurel approach are other planning objectives, including environmental protection, growth control, and access to public resources, which inerit equal consideration in a "reasonable accommodation of competing interests." 46 In Livermore, the California Supreme Court wisely rejected the fair share holding of $M t$. Laurel in favor of a more balanced approach assessing competing priorities.

In National Land Investment Co. v. Board of Adjustment, ${ }^{47}$ the Pennsylvania Supreine Court noted that judges traditionally defer to local zoming decisions due to frustration with "concepts foreign to their legal training."48 The court proceeded, however, to recognize a landowner's constitutional right to use his property, "unfettered, except in very specific instances, by governmental intrusion." 49 The court then rejected the township's proffered justifications for the ordinance-reduction in density, water pollution problems, inadequacy of roads, traf-

43. Id. at 177,336 A.2d at 726. See Williams \& Doughty, supra note 4, at 97 . Williams and Doughty note that the $M t$. Laurel decision could also have been based on federal equal protection guarantees, state equal protection guarantees, requirements of the state's zoning enabling act, the notion of "balanced community," or the right to travel. If the court had rested the decision solely on statutory grounds, the suburban-dominated legislature could nullify the opinion by changing the zoning enabling act. Id. at 98.

44. 67 N.J. at 179,336 A.2d at 727.

45. Id. at 189,336 A.2d at 733 . Recognizing the limits of the ability of local governments to use land-use regulation to mclude low-income housing, the New Jersey Supreme Court modified the "fair share" requirement in Oakwood at Madison, Inc. v. Township of Madison, 72 N.J. 481, 371 A.2d 1192 (1977). Oakwood at Madison held that

to the extent that the builders of housing . . . cannot . . . provide the municipahity's fair sbare of the regional need for lower income housing, it is incumbent on the government body to adjust its zoning regulations so as to render possible and feasible the "least cost" housing, consistent with minimum standards of health and safety, which private industry will undertake . . . .

Id. at 512,371 A.2d at 1207 .

46. 18 Cal. 3d 582, 608-09, 557 P.2d 473, 488, 135 Cal. Rptr. 41, 56 (1976). Justice Mosk, dissenting in Livermore, advocated an approach which is quite similar to the strategy discussed in MI. Laurel. He suggested that any absolute prohibition on housing developinent be presuinptively invalid, and that local regulations that "limit population densities in growing suburban areas may be found invalid unless the community is absorbing a reasonable share of the region's population pressures." Id. at 623, 557 P.2d at 497, 135 Cal. Rptr. at 65 (Mosk, J., dissenting).

47. 419 Pa. 504, 215 A.2d 597 (1966).

48. Id. at 522,215 A.2d at 607 .

49. Id. 
fic congestion, preservation of the "character of the area," and preservation of historic sites in a proper setting - on the grounds that, as to each, the city's objectives could be achieved with less restrictive alternatives. ${ }^{50}$ The court rejected the locahity's remaining asserted interest in controlling growth, holding that such a policy was per se inimical to the State's general welfare. ${ }^{51}$ Because the court did not require a showing that the ordinance actually harmed the regional welfare, the court's recognition of landowners' development rights under its new nondeferential standard apparently would be deternninative regardless of the ordinance's external effects.

The recognition of a nondeference interest in "unfettered developnient" of one's property goes far beyond the traditional treatment afforded property owners in court. When the state does not literally take the land, but inerely reduces its value through zoning requirements, most courts have held that the "taking clause" of the fifth amendment does not apply. ${ }^{52}$ In National Land, the landowners had no fifth aniendment claim under this traditional test because they were permitted to develop on four-acre lots. As the Permsylvania court admitted in a later opimion, "without expressly labeling it as such, this court has einployed a substantive due process analysis in reviewing zoning scheines and has concluded implicitly that exclusionary or unduly restrictive zoning techniques do not have the requisite substantial relationship to the public welfare."53

As a inatter of principle, there does not seem to be a meaningful distinction between this approach and the "Lochnerizing" of the

50. A court recognizing a plaintiff's nondeference interest will require the government to show more than a "rational relationship" between the challenged legislative act and the asserted public interest. Courts have frequently struck down legislative acts interfering with such nondeference interests where less intrusive alternatives exist. See, e.g., United States Trust Co. v. New Jersey, 431 U.S. 1, $29-30$ (1977) (abridgment of contract clause); Shapiro v. Thompson, 394 U.S. 618, 637 (1968) (right to travel); Shelton v. Tucker, 364 U.S. 479, 488 (1960) (free speech); Dean Milk Co. v. City of Madison, 340 U.S. 349, 354 (1950) (state controls on interstate cominerce). See generally Developments in the Law-Equal Protection, 82 HARV. L. Rev. 1065, 1102, 1122 (1969).

51. $419 \mathrm{~Pa}$. at 533, $215 \mathrm{~A} .2 \mathrm{~d}$ at 612 . More recently, the Pennsylvania Supreme Court has adopted the "fair share" standard originally adopted by the New Jersey Supreme Court in Southeru Burlington County NAACP v. Township of Mt. Laurel, 67 N.J. 151, 336 A.2d 713 (1975). See text accompanying notes 42-45 supra. This decision expanded upon Pennsylvania's own judicially adopted limitation on the power of government to restrict the development rights of property owners. Surrick v. Zoning Hearings Bd. of Upper Providence Township, $476 \mathrm{~Pa} .182$, 188, 382 A.2d 105, 108 (1977).

52. Village of Euclid v. Ambler Realty Co., 272 U.S. 365 (1926). One of the arguments rejected by the Euclid court was that the plaintiff liad been deprived of its property without due process, since, as a result of the zoning ordinance, the value of its property was reduced from $\$ 10,000$ per acre to $\$ 2,500$ per acre. Id. at 384 .

53. Surrick v. Zoning Hearing Bd. of Upper Providence Township, 476 Pa. 182, 188, 382 A.2d 105, 108 (1977). 
United States Supreme Court im an earlier judicial era. ${ }^{54}$ California courts have fortunately rejected such antiquated notions. ${ }^{55}$

There is clearly a distinction to be drawn between the test suggested in Livermore, whicli merely calls for application of some statewide concept of public welfare in evaluating a zoning ordinance, and the Pennsylvania approach which, as a matter of constitutional law, defines the substantive conception of public welfare to be applied. While the Livermore reasoning was prompted by the inability of local city councils to balance the competing interests, the Pennsylvama court has indicated no basis-other than judicial fiat-for its decision that property owners cannot fend for themselves im the political arena. No strong argument supports the National Land proposition that a court may choose to give greater protection to the riglit of a property owner to develop his land than to the right of a locality to plan for orderly developinent within its boundaries.

The New Jersey and Pennsylvania experiences indicate that additional nondeference interests, beyond insuring that regional needs are fairly considered, should not be created by the courts. Recognizing this, the New York Court of Appeals has wisely limited independent judicial scrutiny until such time as the legislature adopts a regional zoning mechanism. ${ }^{56}$ It is the thesis of this Comment that California already has a workable statutory and administrative scheme that defines regional housing goals that are to guide local decisioninaking. This scheine provides a competent and politically responsible source to which California courts can look to determine the proper accommodation between housing and other land-use alternatives. ${ }^{57}$

\section{B. The Livernore Standard of Nondeferential Scrutiny}

The Livermore decision does not preclude the possibility of judicial deference to planning decisions inade by state and regional agencies. In remanding the case to the trial court, the supreme court explained in broad terms the process the trial court should einploy in reviewing a challenged ordmance with external impacts. ${ }^{58}$ The extent

54. In the "Lochner" era judges routinely recognized an interest in income from one's property or business as sufficient to invoke judicial scrutiny. See L. TribE, American ConstituTIONAL LAW 427-55 (1978). See also note 23 supra.

55. HFH, Ltd. v. Superior Court, 15 Cal. 3d 508, 542 P.2d 237, 125 Cal. Rptr. 365 (1975), cert. denied, 425 U.S. 904 (1976).

56. Berenson v. Town of New Castle, 38 N.Y.2d 102, 111, 341 N.E.2d 236, 242, 378 N.Y.S.2d 672,682 (1975).

57. See Part III infra.

58. The trial court had initially enjoined enforcement of the ordimance. It found that under Hurst v. Burlingame, 207 Cal. 134, 277 P. 308 (1928), the adoption of the ordimance by initiative violated the plaintiff's right to notice and hearing. The supreme court overruled Hurst. Associ- 
and bounds of the region affected by the ordinance are to be determined as a question of fact. ${ }^{59}$ The court should then attempt to forecast the effect and duration of the restriction, and identify the competmg interests that would be affected by its implementation. ${ }^{60} \mathrm{Fi}-$ nally, the court is to determine "whether the ordinance, in light of its probable impact, represents a reasonable accommodation of competing interests." 61

Livermore leaves unresolved, however, the issue of judicial deference in assessing the propriety of an ordimance with regional repercussions. The court's holding, as stipulated in the decision, does not preclude judicial deference to a legislative (e.g., city council) determination concerning the reasonable relation between an ordinance and the regional welfare. ${ }^{62} \mathrm{Next}$, the court expresses disfavor with the traditional standard of deference, noting that "judicial deference is not judicial abdication" and holding that the ordinance must have a "real and substantial" relation to the public welfare. ${ }^{63}$ But in support of this proposition, the court cites Miller v. Board of Public Works, ${ }^{64}$ the 1925 case that first established the traditional deference standard in reviewing zoning ordinances. Finally, the court pays homage to the traditional language of deference, noting that in many cases "it will be 'fairly debatable' that the ordinance reasonably relates to the regional welfare." It notes, however, that "it cannot be assumed that a land use ordimance can never be invalidated." "65

This ambivalence in Livermore may be attributed to judicial apprelıension that trial courts may "exceed the himits of their competence" 66 in balancing competing regional interests affected by local zoning ordinances. The ambiguity in the case suggests the dilemma facing the courts: either they must continue to defer to a local government when an analysis of the underlying policies indicates that such deference is not justified, or they inust indepcndently weigh competimg policies without the requisite technical expertise. ${ }^{67}$ Fortunately, cur-

ated Home Builders, Inc. v. City of Livermore, 18 Cal. 3d 582, 596, 557 P.2d 473, 480, 135 Cal. Rptr. 4I, 48 (1976).

59. Id. at 607 n.24, 557 P.2d at 487 n.24, 135 Rptr. at 55 n.24.

60. Id. at 608, 557 P.2d at 488,135 Cal. Rptr. at 56.

61. Id. at 609,551 P.2d at 488,135 Cal. Rptr. at 56.

62. Id.

63. Id. at 609,557 P.2d at 489,135 Cal. Rptr. at 57.

64. 195 Cal. 477, 234 P. 381 (1925).

65. Associated Home Builders, Inc. v. City of Livermore, 18 Cal. 3d 582, 609, 557 P.2d 473, 489, 135 Cal. Rptr. 41, 57 (1976).

66. Note, Judicial Limitations on Local Growth Controls: Regional Needs as an Element of the "General Welfare", 66 CALIF. L. Rev. 373, 379 (1978).

67. Courts should, in the absence of an alternative statutory solution, make an independent determination of the reasonableness of an ordmance with external impacts. Livermore may be construed so that whenever a city can present any substantial validation of the reasonableness of 
rent procedures provide a framework for reaching an accommodation of competing land-use policy objectives which may be implemented by Cahifornia's trial courts.

\section{III}

\section{IMPLEMENTING LIVERMORE: THE STATUTORY AND ADMINISTRATIVE FRAMEWORK}

Although California, like most states, has given local governments primary authority for formulating land-use pohicy, it is somewhat unique in the degree to which it requires those local decisions to be consistent with state and regional goals. An exammation of the statutory and administrative mechanisms by which these goals are formulated will demonstrate their usefulness to the courts in evaluating local government actions.

\section{A. The Basic Structure of Land-Use Regulation}

The basic structure of land-use regulation in California is outlined in local planning, zoning, and subdivision control statutes. The "local

its ordinance, courts will uphold the ordinance regardless of the substance of contrary evidence demonstrating the inadequacy of the challenged ordinance. An analysis of the policies which led the court in Livermore to depart from traditional deference, however, compels a contrary conclusion. Under the Livermore theory a city council should not be entitled to deference to its judgment that its own ordinance is a reasonable accommodation of competing interests. A council is no more capable than a court of identifying the impact of the ordinance on residents of the region. Since a council owes its contmued political existence to the support of its citizens, it is not likely to be able fairly to weigh benefits to its constituents against costs to those who are powerless to vote them out of office. In this sense, courts have greater competence than the city councils, since courts are generally not immediately answerable to a political constituency.

In subsequent cases, California courts would be well-advised to heed the wisdom of the New York Court of Appeals, which recently faced similar issues. In Berenson v. Town of New Castle, 38 N.Y.2d 102, 341 N.E.2d 236, 378 N.Y.S.2d 672 (1975), the court also imposed upon cities an obligation to consider the needs of the region as well as the needs of its own citizens in establishing zoning regulations affecting new housing. The court further held that, at least until the state created regional zoning bodies, "the court must assess the reasonableness of what the locality has done." Id. at 111,341 N.E.2d at 243,378 N.Y.S.2d at 682 . Berenson clearly ruled out deference to a local judgment that the challenged zoning ordinance reasonably accommodates regional needs: "While the people of New Castle may fervently desire to be left alone by the forces of change, the ultimate determination is not solely theirs." Id. Another New York court subsequently expressed the underlying policy concern: issues of regional imterest would, absent independent judicial scrutiny, be decided by local governments which are either unable or unwilling to weigh fairly these external concerus. Horizon Adirondack Corp. v. State, 88 Misc. 2d 619, 630, 388 N.Y.S.2d 235, 243 (Ct. Cl. 1976).

The Cahfornia Supreme Court should therefore forthrightly recognize a nondeference interest of residents of a metropolitan region in having their needs fairly considered in zonimg determinations which affect thein. By creating this nondeference interest, the judiciary should not pay heed to any "fairly debatable" justification which a city can make on behalf of its ordinance; courts should reach their own conclusions as to whether the ordinance represents "a reasonable accommodation of competing interests." 
planning" chapter of the Government Code ${ }^{68}$ describes in detail the governmental structure of local planning and responsibilities. This chapter requires all cities and counties to establish planning coinmissions and planning departments with specific powers. The heart of the planning law is the general plan, ${ }^{69}$ considered to be the "comprehensive, long-term general plan for the physical development of the county or city."70 It is the primary statement of goals and policies from which a detailed regulatory scheme is to follow. The plan must contain a number of "elements" which set forth developinent policies, objectives, primciples, and standards for land use, transportation circulation, resource conservation, open space, seismic safety, noise, scenic highways, safety, and, most important for our purposes, housing. ${ }^{71}$ In addition, the plan is required to be internally consistent. ${ }^{72}$

The locality's general plan is not self-executing. Although it may show detailed maps of certain areas and their uses, further action is necessary to put its policies into effect. The primary measures available to local governments for effectuating their general plans are provided by the zoning chapter ${ }^{73}$ and the Subdivision Map Act ${ }^{74}$ of the Government Code. The zoning chapter is the enabling act prescribing in detail local zoning procedures and authority. The chapter is applicable to counties and general law cities but not to charter cities. ${ }^{75}$ In addition to the powers prescribed in the zoning chapter, all cities and counties liave imdependent zoning authority which may be exercised if it does not conflict with state law. ${ }^{76}$

The Subdivision Map Act controls all divisions of real property contaiming five or more parcels. Unlike the zoning chapter it is applica-

68. CAL. Gov't CODE $\$ \S 65100-65700$ (West 1966).

69. Id. $\$ \S 65300-65302$.

The requirement of a general plan with certain mandatory elements is the only part of the planning chapter that applies to charter cities. Id. § 65700 . "Charter" cities are those localities which have adopted a local charter establishing their own structure and superseding state laws with respect to "municipal affairs." CAL. ConsT. art. Xl, §5. "General law" cities have their structure prescribed by state statutes. Although the application of state land-use legislation to charter cities has been controversial, see Comment, Land-Use Controls, Externalities, and the Municipal Affairs Doctrine: A Border Confict, 8 Loy. L.A.L. REv. 432 (1975), recent cases indicate that planning is a matter of legitimate statewide concern, see, e.g., Selby Realty v. City of San Buenaventura, 10 Cal. 3d 110, 120, 514 P.2d 111, 117, 109 Cal. Rptr. 799, 805 (1973), and the application of the general plan requirement to charter cities has accordingly not been challenged.

70. CAL. GOV'T CODE $\S 65300$ (West 1966).

71. Id. $\S 65302$.

72. Id. $\S 65300.5$ (West Supp. 1978).

73. Id. $\S \S 65800-65912$.

74. Id. $\S \S 66410-66499.58$.

75. Id. $\$ 65803$.

76. Birkenfeld v. City of Berkeley, 17 Cal. 3d 129, 140, 550 P.2d 1001, 1009, 130 Cal. Rptr. 465, 473 (1976); Scrutton v. County of Sacramento, 275 Cal. App. 2d 412, 79 Cal. Rptr. 872 (3d Dist. 1969). 
ble to charter cities as well as general law cities and counties. The Act controls the complex process of providing unimproved property with site improvements, utilities, and streets for further development, and mvolves many engmeering, design, social, and economic considerations. Subdivision control is most frequently apphed to undeveloped land, particularly urban fringe areas. ${ }^{77}$

\section{B. The Regional Housing Need Factor in Local General Plans}

The Government Code provides that the housing element of a local general plan must provide for the housing needs of people within the commumity:

A housing element, to be developed pursuant to regulations established under Section 41134 of the Health and Safety Code, consisting of standards and plans for the improvement of housing and for provision of adequate sites for housing. This element of the plan shall make adequate provision for all economic segments of the community. ${ }^{78}$

The housing element, then, must consist of a body of plans, goals, and policies which provide for both the improvennent of housing, and the "provision of adequate sites" for housing. Although the exact form and content of a housing element are by no means clear in this language, the key point for present purposes is the duty owed to "all economic segments of the commumity." At issue remains the judicial enforceability of this duty.

Whether the legislature intended to impose a duty upon local governments to consider regional housing needs in making land-use decisions is a question of the proper interpretation of the word "community" as used in the applicable statute. ${ }^{79}$ An examination of the planning and zoning statutes indicates that the legislature carefully used the terins "city" and "county" in a manner suggesting that "community" is not synonymous with those terms. ${ }^{80}$ In every context, ${ }^{81}$

77. See generally California Continuing Education of the Bar, Practice Under THE NEW SUBDIVISION MAP ACT (1975).

78. CAL. Gov'T CODE § 65302(c) (West Supp. 1978) (emphasis added).

79. Id.

80. See CAL. Gov'T Code $\$ \$ 65100,65300,65800$ (West 1966).

81. Varying instances in which the definition of community becomes important iuclude: "community standards" in obscenity cases, In re Giannini, 69 Cal. 2d 563, 573, 446 P.2d 535, 542, 72 Cal. Rptr. 655, 662, cert. denied, 395 U.S. 910 (1968); libel, Scott v. Times-Mirror Co., I8I Cal. 345, 365, 184 P. 672, 681 (1919); medical malpractice standards, Gist v. French, 136 Cal. App. 2d 247, 270, 288 P.2d 1003, 1018 (2d Dist. 1955); reputation in the community (criminal), People v. Carnavacci, I19 Cal. App. 2d 14, 258 P.2d I 121 (2d Dist. 1953). The only statutory definition of community is found in CAL. HEALTH \& SAFETY CODE $\$ 33002$ (West 1973), a portion of the Community Redevelopment Law. It defines "community" as "a city, county, city and county, or Indian tribe, band, or group, which is incorporated or which otherwise exercises some governmental powers." This definition is tailored to the needs of the Community Redevelopment Law, and shows that where the legislature intends a narrower interpretation of the term, it will so state. 
"community" has been used to denote some common interest, trait, or possession. In California, and in other states, "communty" refers to an area of common interest extending beyond municipal boundaries. ${ }^{82}$

A common interest in housing supply will generally extend beyond municipal boundaries. For example, nonresidents who work or attend school within a locality could move into the locahty if the housing supply expands. Moreover, the housing supply available to residents of neighboring areas is affected by the zoning actions of neighboring cities which restrict housing construction. In a large metropohs contaming many jurisdictions, economic and market forces cross city lines in affecting the price and volunie of the available housing supply. ${ }^{83}$

The legislature's intent to impose regional responsibilities on local

82. Keech v. Joplin, 157 Cal. 1, 106 P. 223 (1909), considers community to be a descriptive term which is to be interpreted to carry out the purpose of the given legislation. Faced with a statute authorizing the formation of flood control districts on the petitions of the "owners of a majority of the lands of any farming or other community or neighborhood," the court explaincd that "[t]o give adequate, practical, and lawful protection against the [problem], it is necessary that all whose lands are likely to be affected . . . should unite . . ." Although the court felt that "community" referred "to the people who reside in a given locality in more or less proximity," it also noted that "[w]hat one person would consider a single community or ncighborhood, another might believe to embrace two or more commumities or neighborhoods." Rathcr than deflning community, the court concluded that "commurity and neighborhood is to be taken as a matter of description, but not of limitation," because "of the evident object of the act." Id. at 10-12, 106 P.2d at 227. Because of the nature of the task of flood control, the court refused to limit the meaning of "community" to the citizens of one city.

In Virginia, where courts are required by statute to approve requests for town charters only if "the general good of the community is promoted," a court disapprovcd a requcst on the grounds that the interest of other nearby settlements would probably be seriously prejudiced, "[t]he word 'community' . . . not [being] necessarily confincd to the proposed corporate limits." Bennctt v. Garrett, 132 Va. 397, 406, 112 S.E. 772,775 (1922). An lllinois court found the construction of a water works to serve several towns was within the provisions of a zoning ordinance allowing construction of a "community water works." Odd Fellows Oakridge Cemetery Ass'n v. Oakridge Cemetery Corp., 14 1ll. App. 2d 378, 383, 144 N.E.2d 853, 857 (1957).

A dictum in Ybarra v. City of Los Altos Hills, 503 F.2d 250, 254 (9th Cir. 1974), conclusorily states that "community" as used in Government Code $\$ 65302$ (c) does not refer to any area beyond the city's boundaries. Although a Ninth Circuit opinion would normally be influential, even on a question of state law, the court's failure to provide any analysis undermines the utility of this precedent.

83. Although full explanation of these forces can be highly technical, it is apparent that our transportation system creates pliysically mobile lousing consuners for whom acceptable housing may be located within a large geographical area, covering many cities. Additionally, the incrcasing social and physical mobihity of the population breaks down municipal loyalties. This leaves functional location, amenity, and price as the primary variables in the consumcr's choice, which are hardly affected by the drawing of boundary hnes. When municipal actions restrict the metropolitan housing supply, local residents are affected by increased competition for remaining housing. See H. Gans, The Levittowners 31-41 (1967), reprinted in D. Mandelker \& R. Montgomery, Housing in America: Problems and Perspectives 177-87 (1973). Although the exact extent of effect of municipal zoning on neighboring cities is debatable, its existcnce has been clearly documented. See also U.S. National Comm'N on URban Problems, Buildino the American City 211-17 (1969); U.S. President's Committee on Urban Housina, A DeCENT HOME 140 (1969). 
governments is evidenced by a number of aspects of the planning chapter. For example, the area covered by the general plan is not limited to the jurisdiction's legal boundaries, but includes "any land outside its boundaries which . . . bears relation to its planning." 84 Adjoining cities and counties inay adopt the regional portions of the plan. ${ }^{85}$ The plan also must be submitted to the county Local Agency Formation Commission and all adjoining cities. ${ }^{86}$ Additionally, although the zoning chapter contains an express legislative intent to allow localities maximuin latitude, ${ }^{87}$ the local planning chapter contains no such provision. Instead, the legislature has imposed upon local governments a detailed and pervasive regulatory system. The plan requirements also are specifically applicable to charter cities, ${ }^{88}$ despite a tradition of independence from state regulation. ${ }^{89}$

Even absent such a clear indication of legislative intent, a California court would have reason to give the ambiguous statutory term "comnunity" the suggested regional definition im light of adoption of that interpretation of the statute by the Department of Housing and Community Development, the administrative agency responsible for its implementation..$^{90}$ The regulations giving effect to the planning chapter define "coininumity" as the "housing 1narket area," which subsequently is defined as a geographical area "within which local interaction has resulted in an economic and social interdependence with respect to the provision of housing, employinent and service opportunities." $" 1$

The current regulations do not inerely define the concept of "cominunity." These regulations ${ }^{92}$ coinpletely implement the housing eleinent statute by setting the procedural, methodological, and substantive requirenients for their preparation and content. In addition, they provide for the statutorily authorized review of the housing elements by the Departınent of Housing and Community Development.

The central elenient of the regulations in this context is the re-

84. CAL. Gov'T CODE $\S 65300$ (West 1966).

85. Id. $\S 65301$.

86. Id. $\S 65305$ (West Supp. 1978). The Local Agency Formation Commission is a county body established pursuant to CAL. Gov'T CODE $§ \S 54773-54799.5$ (West Supp. 1978) and is responsible for approving all boundary changes and new incorporations, aud for planning future changes within the county.

87. Id. $\S 65800$.

88. Id. $\S 65700$.

89. See Sato, "Municipal Affairs" in California, 60 CALIF. L. Rev. 1055 (1972).

90. 25 CAL. ADMIN. CODE $\S 6418$ (1977). These regulatious are promulgated pursuant to Cal. Health \& SAfETy Code $\$ 41134$ (changed to Cal. Health \& Safety Code $\S 50459$ by 1977 Cal. Stats. ch. 610 \& 2), as authorized by CAL. Gov'T CODE § 65302(c) (West Supp. 1978).

91. 25 CAL. ADMIN. CODE §6410(f) (1979).

92. See note 88 supra. 
quirement of a "fair share" allocation, to be calculated by either the local Council of Governments or the Department of Housing. This formula specifically allocates to each city responsibihty for a proportionate share of low- and moderate-income housing needs. ${ }^{93}$

The regulations also establish citizen participation requirements, and stipulate that all municipalities must both solicit state and federal funds and develop specific programs for meeting housing needs. ${ }^{94} \mathrm{Fi}$ nally, both the detail and review mechamism of the regulations serve a vital function by codifying state and regional policies which the courts may assess in evaluatimg land-use decisions.

\section{The Binding Nature of the Housing Element Regulations}

There has been a considerable controversy over the issue of whether the housing element regulations are legally bindimg upon cities.95 Although often referred to as "guidelines,"96 the housing element regulations are to be distmguished from the advisory guidehines promulgated for the other elements of the general plan. ${ }^{97}$ The housing element requirement refers to regulations, not guidelines, to be adopted according to Health and Safety Code section $41134 .{ }^{98}$ That section requires that the regulations be adopted in accordance with the California Administrative Procedure Act (APA), ${ }^{99}$ which provides that regulations "implement, interpret, or make specific" statutes. ${ }^{100}$ The APA does not indicate that such regulations are to be considered any less binding than the statute itself. In fact, the attorney general has concluded that actions required to be taken pursuant to the APA are ordmarily intended to be bimding. ${ }^{101}$ Additionally, the planning law

93. 25 Cal. Admin. Code $\S \S 6420-6436$ (1977).

94. Id. $\$ \$ 6432,6434$.

95. See Letter from Arnold Sternberg, then Director of Housing and Community Development, to All Interested Persons (Apr. 23, 1977) (accompanying third draft of housing regulations).

96. 25 CAL. AdMin. CODE $\$ 6402$ (1979).

97. The other elements are found in CAL. Gov'r CODE $\S 65302$ (West Supp. 1978).

98. Cal. Health \& Safety Code $\$ 41134$ (changed to Cal. Health \& Safety Code $\S 50459$ by 1977 Cal. Stats. ch. $610 \& 2)$.

99. Id. $\$ \$ 11370-11528$ (West 1966).

100. Id. $\$ 11371$.

101. 28 Op. Att'y Gen. 227 (1956).

Those arguing that the regulations are not binding have pointed to language in CAL. Gov'T CODE $§ 65040.2$ (West Supp. 1978) regarding advisory guidelines, which can be quite confusing if taken out of context. This section is part of a group of sections vesting certain responsibilities in the Office of Planning and Research, an independent executive departinent which reports directly to the Governor. Section 65040.2 provides that the Office is to develop guidelines for all of the elements of the general plan. It further provides that the Office may seek assistance in the preparation of the guidelines from other departments of state government, that it may revise the guidelines, and that the guidelines shall be advisory. This last point, that the "guidelines shall be advisory to each city and county," has frequently been misinterpreted to apply to the housing element regulations. 
requires the housing eleinent to be "developed pursuant to regulations," 102 which clearly indicates that the regulations are to have a legally binding character. ${ }^{103}$

Even if the statutory language is not sufficient to make the regulations binding, such effect inay be gained when they are read in conjunction with the supreme court's deeision in Livermore. The regulations provide a court with an authoritative interpretation by a politically accountable agency of what a "reasonable accommodation of coinpeting interests" requires, and such interpretations are upheld unless clearly erroneous. ${ }^{104}$ This rule of construction provides the court an opportunity to defer on difficult policy questions to a party with greater competence to shoulder the burden of interpretation and administration. This

However, analysis of the context and the specific language of the remainder of the section shows that it is not intended to apply to the housing element regulations at all. The section is part of a series of laws defining the responsibilites of the Office of Planning and Research, and as such, it can reasonably be construed to apply only to their activities, not the separate activities of the Department of Housing and Community Developinent. In addition, none of the other guidelines to be developed by the Office of Planning and Research find any independent authorization in the General Plan requireinent itself, and none are referred to as regulations.

Housing element regulations are also exempt from this section due to a specific, though clumsily worded, exception. The first paragraph provides that "[f]or purposes of this section, the guidelines prepared pursuant to Section 41134 of the Health and Safety Code shall be the guidelines for the housing element required by Section 65302." CAL. Gov'T CodE $\$ 65040.2$ (West Supp. 1978). The clear intent of this sentence is to note that housing element regulations are provided for elsewhere, and therefore are not to be the responsibility of the Office of Planning and Research under this section. Althougl the phrase "for purposes of this section" is somewhat unclear in regard to whether this is a specific exemption, it does seem clear that the other purposes of this section-development and revision of the guidelines by the Office-cannot possibly apply to the housing element regulations, suggesting that the section itself is not intended to apply to thein.

The binding nature of guidelines for the California Environmental Quality Act, issued under Cal. Pub. Res. Code $\S 21083$ (West 1977), has gone unquestioned by the courts, although its language provides a much weaker basis for doing so. Bozung v. Ventura County Local Agency Formation Comm., 13 Cal. 3d 263, 529 P.2d 1017, 118 Cal. Rptr. 249 (1975); Day v. City of Glendale, 51 Cal. App. 3d 817, 124 Cal. Rptr. 569 (2d Dist. 1975).

102. CAL. Gov't CODE $\S 65302$ (c) (West Supp. 1978).

103. The legislative history of $\$ 41134$ also demonstrates that the legislature intended the regulations to be binding. Originally, the provision for adoption of housing element guidelines was contained in Health and Safety Code $\$ 30741$, which did not expressly require that they be adopted in accordance with the APA. In 1972, the attomey general ruled that since the lousing element requires regulations, rather than guidelines, they must be adopted in accordance with the APA. 55 Op. Att'y Gen. 380 (1972).

In 1975, the Governor convened a special session of the legislature, concurrent with the regular session, to consider housing legislation. Senate Daily Journal, Feb. 17, 1975, at 1 (1975-76 First Extraordinary Session); Assembly Daily Journal, Feb. 17, 1975, at 1 (1975-76 First Extraordinary Session). Among other things, the session resulted in the creation of the California Housing Finance Agency and a revamping of the Departinent of Housing and Community Development. 1975 Cal. Stats. 1st Ex. Sess. ch. 1, ch. 2.

104. Los Angeles Employees Union v. Los Angeles Bd. of Educ., 12 Cal. 3d 851, 854, 528 P.2d 353, 355, 117 Cal. Rptr. 537, 539 (1974); Rivera v. Fresno, 6 Cal. 3d 132, 140, 490 P.2d 793, 797, 98 Cal. Rptr. 281, 285 (1971); Morris v. Williams, 67 Cal. 2d 733, 748, 433 P.2d 697, 707, 63 Cal. Rptr. 689, 699 (1967). 
deference would be especially significant if the Department of Housing and Community Development had reviewed a local housmg element for conformity with "nonbinding" regulations. Simce the Department is clearly authorized to make such a review, its evaluation would likely prove determinative in most cases. ${ }^{105}$

\section{Local Land-Use Decisions and the General Plan: The Consistency Requirement}

As noted earlier, although a general plan is often quite specific, it is not self-executing. It is inerely a body of objectives and policies that neither compels nor prohibits conduct. While it may show detailed maps of certain areas and their uses, additional measures are necessary to put its policies into effect. To ensure that the local general plan is actually used to guide decisionmaking, the legislature has required that various local actions be consistent with the general plan. ${ }^{106}$

\section{Zoning \\ a. Statutory Mandate}

To insure the effectiveness of the general plan as a means of enforcing local responsibilities, the legislature requires that local zonmg ordinances be consistent with the local general plan. ${ }^{107}$ This requirement applies only to counties and general law cities, ${ }^{108}$ and to the City of Los Angeles. ${ }^{109}$

According to Government Code section 65860(a)(ii), consistency exists wlien "the various land uses authorized by the ordinance are compatible with the objectives, policies, general land uses, and prograins specified in such a plan." Although this definition may not set fortl any workable standards for evaluating the consistency of a zoning ordinance if the plan elements are vague, the specificity that the regulations require of a housing element are such that inconsistency should be easily ascertainable.

105. Cal. Health \& Safety Code $\$ 50459$ (West Supp. 1978).

106. Of course, the substantive requirements of the general plan are necessary to prevent a locality from simply transforming its plan to be consistent with whatever zoning it chooses to adopt. This need to go beyond consistency and to evaluate and constram the content of the general plan has been considered in R. BABCOCK, THE Zoning GAME 122-23 (1966).

107. CAL. Gov't CODE $\S 65860$ (West Supp. 1977).

108. Id. \& 65803 (West 1966).

109. Id. $\$ 65860$ (d), 1978 Cal. Legis. Serv. ch. 357 . The limitation of the consistency requireInent to Los Angeles was based on fear of erosion of home rule and excessive costs. See Comment, Defining and Implementing Local Plan-Land Use Consistency in Calffornia, 7 ECOLOGY L.Q. 753,757 n. 25 (1979). 


\section{b. Due Process Requirement}

Even where a statutory consistency requirement is not apphicable, such as in the case of charter cities, ${ }^{110}$ the act of the locality must still be reasonably related to a legitimate goal. This is not a novel concept, but its use in requiring plan and zoning consistency has yet to be explored.

The earhest zoning cases im Cahfornia held that zoning was a justifiable use of the police power when carried out "in pursuance of a comprehensive plan of community development." 111 Such cases-were a specific apphication of the due process doctrine that an exercise of pohice power must be reasonably related to a legitimate objective, e.g., community developinent.

The due process requirement of consistency would appear to be more stringent in hight of the statutory requirement that local governinents develop general plans to be the "Constitution for future developinent of the city."112 Courts sliould consider the goals stated in the general plan as the ones to which the zoning ordinances must reasonably be related under the due process test. ${ }^{113}$ Although courts often defer to legislative bodies on questions of policy choice, it is not unusual for the courts to subsequently hold them estopped from acting inconsistently with those choices. ${ }^{14}$ Thus, although a locality, within limits, may choose the goals that its general plan is to embody, it does not follow that it may deviate from them as it chooses. Likewise, a city will not be allowed to argue that its general plan is a shain and that the zoning is actually related to constitutionally permissible though unstated objectives.

Recognition of this test is crucial both because it imposes a consistency requirement on charter cities and because its constitutional nature renders it invulnerable to legislative dilution or nullification. It has been noted elsewhere that the legislative history of the statutory

110. For a list of all charter and general law cities, see D. HAGMAN, CALIForNIA ZoNING Practice (1971). About 70 of Cahfornia's 400 cities are charter cities.

111. McCarthy v. City of Manhattan Beach, 41 Cal. 2d 879, 885, 264 P.2d 932, 935, cert. denied, 348 U.S. 817 (1953); Zahn v. Los Angeles Bd. of Pub. Works, 195 Cal. 477, 234 P. 381 , error dismissed, 273 U.S. 781 (1925).

112. O'Loane v. O'Rourke, 231 Cal. App. 2d 774, 782, 42 Cal. Rptr. 283, 288 (2d Dist. 1965).

113. In Hall v. City and County of Honolulu, 56 Hawaii 12I, 530 P.2d 737 (1975), the Supreme Court of Hawaii required zoning and the local general plan to be consistent without the benefit of a specific statutory requirement. See Baker v. City of Milwaukie, 271 Or. 500, 533 P.2d 772 (1975); State ex rel. Standard Mining \& Dev. Corp. v. City of Auburn, 82 Wash. 2d 321, 510 P.2d 647 (1973). All of these cases rest on interpretations of overall statutory intent and structure, however, and not on constitutional due process. Baker provides the most thorough analysis. See also Haar, In Accordance with a Comprehensive Plan, 68 HARv. L. REv. 1154 (1955); Haar, The Master Plan: An Impermanent Constitution, 20 LAw \& CoNTEMP. ProB. 353 (1955).

114. See Hadley v. Junior College Dist., 397 U.S. 50 (1970), where a local decision to elect school trustees subjected the school district to the application of constitutional apportioninent standards. 
consistency requirement shows the clear intent of the legislature that charter cities not be subjected to that requirement of consistency. ${ }^{115}$ Although this history might prevent judicial developinent of a consistency requirement as a result of a construction of the state planning law, ${ }^{116}$ it cannot prevent a constitutionally based due process review of government actions.

A due process requirement of consistency will also be important in general law cities because of its freedom from the narrow procedural constraints of the statutory consistency requirement, particularly with regard to standing requireinents and delay before bringimg suit. ${ }^{117}$

Since this test is only another aspect of the norinal due process review of land-use decisionmaking, the local government's decision should be given the same degree of deference as in other land-use cases. Thus, the requireinent of consistency between the zoning and inost plan eleinents will be easily satisfied under the traditional deferential standard of review that is discussed above. ${ }^{118}$ Under Livermore, however, when the zoning fails to impleinent the housing eleinent of the plan, a inore stringent standard of review would be invoked. Accordingly, the court would analyze whether the zoning represents a reasonable accommodation of the coinpeting interests expressed in the plan. Clearly, the appropriate standard of review needs to be developed, and may vary with the particular interests at stake. Livermore makes clear, however, that "judicial abdication" will no longer be sanctioned in exclusionary zoning situations.

\section{Subdivisions}

The Subdivision Map Act, ${ }^{119}$ which applies to both charter and general law cities, requires that approved subdivisions and their provisions for design and improvement be consistent with the local general plan. ${ }^{120}$ The subdivision consistency requirement is snnilar in its main poimts to the zoning consistency requirement. Certain technical requirements of the Subdivision Act may provide additional bases to challenge a subdivision, but would provide little long-run benefit to plaintiffs. For example, when approving a subdivision, the locality is specifically required to find that the subdivision is consistent with the general plan. ${ }^{121}$ Although a plaintiff would have an additional challenge to the subdivision on the ground that no such finding was inade,

115. See Comment, supra note 109 , at 757 n.25.

116. See note 112 supra.

117. See text accompanying notes 110-11 supra.

118. See text accompanying notes 8-9 supra.

119. CAL. Gov'T Code $\$ \S 66410-66499.58$ (West Supp. 1978).

120. Id. 66473.5 .

121. Mountain Defense League v. Board of Supervisors, 65 Cal. App. 3d 723, 135 Cal. Rptr. 
this would be of little practical significance since a court would probably only remand the decision to the locality for such a finding without actually ordering a reconsideration of the decision. ${ }^{122}$ After the locality made the required finding, the plaintiff would be left to the same grounds that he or she has to challenge a zoning ordinance. The only result of the plaintiff"s "extra ground" under the subdivision consistency requirement is a short delay in final resolution of his or her challenge.

In addition to the statutory requirements, the saine due process considerations that require local zoning decisions to be consistent with the general plan would require consistency in the approval of subdivision inaps.

\section{E. Judicial Action Under Livermore}

Livermore and the statutory and administrative mechanisms discussed above both advance the proposition that local land-use decisions be made consistent with statewide needs for low- and moderateincome housing. Read together, they can come nearer that goal than either can alone. First, the statutory scheme clearly provided a solution to the probleins with judicial competence created when the supreme court adopted a nondeference standard in Livermore. While the housing element regulations provide standards by which local general plans can be judged, local plans, once promulgated under the state regulations, offer guidelines for a critical assessinent of zoning and subdivision decisions.

The strategic implications of these regulations in exclusionary zoning litigation are significant. Rather than arguing that the judiciary must abandon traditional deference in favor of taking on the responsibilities of making an independent judgment on extremely coinplex matters of fact which may be beyond the competence of the court to inaster, the plaintiff presents the court with a workable alternative. The court need not choose between traditional deference to the locality and embarking on a major and difficult project, but may defer to a competent and existing system that is itself subject to review for abuse of discretion. Likewise, when a plaintiff asks the court to review the consistency of a local land-use decision with a general plan, the plan itself is a resolution of competing land-use objectives by local governinent made under the watchful eye of the state administrative agency.

588 (4th Dist. 1977); Woodland Hills Residents Ass'n v. City Council, 44 Cal. App. 3d 825, 118 Cal. Rptr. 856 (2d Dist. 1975).

122. Woodland Hills Residents Ass'n v. City Council, 44 Cal. App. 3d 825, 118 Cal. Rptr. 856 (2d Dist. 1975). 
Again, the court need not determine policy but only need apply previously formulated policy to a specific set of facts.

On the other hand, although the state planning law provides substantive standards of local government responsibility and competent review and administration of those standards, it lacks some of the powers necessary to enforce those standards. Both the State and the Department have standing to challenge local government actions in court, but. the Department does not have the power to issue orders compelling coinphiance with its regulations. ${ }^{123}$ Litigation by the State or the Department is of course limited by budgetary constraints. In addition, because the Department's review powers are permissive rather than inandatory, it is unclear whether it could be compelled to provide a review of a local housing element. ${ }^{124}$

Land-use hitigation has traditionally been filed by private parties. Accordingly, much of the responsibility for enforcing these new standards will remaim, where other approaches are meffective, with private hitigants. Here, Livermore assumes its greatest importance. Relieved of the duties of establishing and administering the substantive standard of local responsibility, the court can forthrightly apply the more demanding standard of review established in Livermore and can construe the state planning law as is necessary to effectuate its goals.

123. Standing of the attorney general is affirmed in People ex rel. Younger v. County of El Dorado, 5 Cal. 3d 480, 487 P.2d 1193, 96 Cal. Rptr. 553 (1971). A state departunent responsible for administering a law has standing to seek mandainus requiring its enforcement even where that departinent does not have the authority to order compliance with the law. Brown v. Superior Court, 5 Cal. 3d 509, 487 P.2d 1224, 96 Cal. Rptr. 584 (1971); Board of Social Welfare v. County of Los Angeles, 27 Cal. 2d 98, 162 P.2d 627 (1945).

Even without judicial sanction, a negative review of a local housing element by the Department of Housing and Community Development could have severe repercussions for a locality in the form of loss of substantial federal funding. Under Office of Management and Budget Circular A-95, the Departinent reviews local apphications for entitlement grants under the federal Community Developinent Block Grant Prograin, Pub. L. No. 93-383, 42 U.S.C. § 5301, Pub. L. No. $95-$ 128. A negative review by the Department may mean denial of the application. Further, many of the data-gathering and planning requirements for the housing element and the "block grant" prograin are drawn similarly such that a violation of the housing element regulations may engender a violation of the federal law as well.

124. It is possible that inandamus inay lie for abuse of discretion in refusing to review a local housing eleinent. Inglin v. Hoppin, 156 Cal. 483, 491, 105 P. 582, 585 (1909). See also 5 B. Witkin, California Procedure Extraordinary Writs $\$ 77$ (2d ed. 1971 \& Supp. 1979). Availability of the writ might be aided by a mle of statutory construction which holds that the word "may" will be construed as inandatory where there is an important interest in the performance of the authorized act necessary to effectuate the intent of the statutes. Uhl v. Badaracco, 199 Cal. 270, 282, 248 P. 917, 921-22 (1926); People ex rel. City of Bellflower v. Bellflower County Water Dist., 247 Cal. App. 2d 344, 352, 55 Cal. Rptr. 584, 589 (2d Dist. 1966). See also 45 CAL. JuR. Statutes $\$ 157$ (2d ed. 1958 \& Supp. 1978). Because of the interest of the public in the full effcctuation of the state planning law and the importance of the review by the Department of Housing and Community Developinent in deterınining the validity of local housing elements, the language of CAL. Health \& SAFETY Code $\$ 50459$ (West Supp. 1978), providing that the Department "nıay" review housing elements, is a strong candidate for this construction. 


\section{F. Judicial Enforcement of the Statutory Mandates}

Challenges to a locality's general plan should be determined by looking at the housing element requirements under the planning chapter. As noted earlier, that cliapter places a inandatory duty upon local legislative bodies to promulgate general plans that consider regional housing needs. The remaining questions are how such a duty is to be enforced in private litigation and by whoin.

\section{Form of Action}

When a statute places a inandatory duty upon a local legislative body, that duty may be enforced by a writ of mandamus. ${ }^{125}$ In order for the writ to issue, there inust be no other adequate remedy, and violation of the statute inust be present rather than anticipated. ${ }^{126}$ Thus, the challenge will not lie until the locality has either missed the deadline for adoption of the plan or finally adopted the allegedly madequate plan.

Although mandainus is available, an action for declaratory judgment ${ }^{127}$ is not. In Selby Realty Co. v. City of San Buenaventura, ${ }^{128}$ it was lield that the declaratory judgment action requireinent of an "actual controversy" prevented a landowner's inverse condemnation claim from being heard until the city actually denied him use of his land. ${ }^{129}$ Neither the holding nor its rationale, which sought to prevent the landowner from interfering with the planning process, would apply in a mandanus action, particularly where the plaintiffs seek to enforce a public duty. ${ }^{130}$

\section{Standing}

Standing to challenge a plan through mandamus is easily obtamable because of the broad public interest at stake in the execution of a general plan.

California courts have carved out a "public interest" exception to

125. See People ex rel. Younger v. County of El Dorado, 5 Cal. 3d 480, 487 P.2d 1193, 96 Cal. Rptr. 553 (1971). See also 5 B. W1TK1N, CALlFornia Procedure Extraordinary Writs §§ 61 69 (2d ed. 1971 \& Supp. 1979). Even when the required act involves the exercise of discretion, the act may be reviewed for abuse of discretion. Id. at $\$ 77$.

126. See Cal. Civ. Proc. Code $\S 1086$ (West 1955). See also 5 B. Witkin, California Procedure Extraordinary Writs $\$ 64$ (2d ed. 1971 \& Supp. 1979).

127. Cal. Civ. Proc. Code $\$ 1060$ (West 1955).

128. 10 Cal. 3d 110, 512 P.2d 111, 109 Cal. Rptr. 799 (1973).

129. To date, Selby has been applied only in inverse condemnation actions. See HFH, Ltd. v. Superior Court, 15 Cal. 3d 508, 542 P.2d 237, 125 Cal. Rptr. 365, cert. denied, 425 U.S. 904 (1975); Dale v. City of Mountain View, 55 Cal. App. 3d 101, 107-08, 127 Cal. Rptr. 520, 523 (1st Dist. 1976); Smith v. State, 50 Cal. App. 3d 529, 534, 123 Cal. Rptr. 750, 755 (2d Dist. 1975).

130. See text accompanying notes 93-101 supra. 
the usual requirement that the writ must be sought by a "party beneficially interested"131 in its issuance. When the writ is sought to compel performance of a "public duty" rather than a private duty owed to the plaintiff specifically, the plaintiff inay assert the interest of every citizen in having the laws properly executed. ${ }^{132}$ The California public interest exception was apphied, for example, in American Friends Service Committee $v$. Procunier, ${ }^{133}$ in which nonprofit organizations concerned about prisoners' rights were allowed to seek mandamus to require prison regulations to be formulated in accordance with the Cahfornia Administrative Procedure Act.

There is no fixed threshold of public imterest, but rather a shiding scale on which the degree of public interest shown correspondingly reduces the degree of personal imterest required. ${ }^{134}$ In analyzing the extent of the public interest, two important factors noted by courts are (a) the imdications of a general public or statewide importance of the law ${ }^{135}$ and (b) the relative ease with which the obligation night be enforced by inore specifically interested parties. ${ }^{136}$

An assertion of standing to challenge the housing element of a general plan should satisfy these tests. The statewide importance of planning has been noted by the supreme court itself ${ }^{137}$ and the importance of housing by the legislature. ${ }^{138}$ In addition, the duty is clearly not imtended to benefit any particular individuals who would come within its terms, but rather is designed to msure an adequate general housing supply for the population-at-large.

Any resident or property owner of the defendant city is a member of the public to whoin the local officials owe their duty and who, at a minimuin, has an interest in having his or her city plaimed in accordance with the law. This combimation of personal and public interests should readily facilitate standing for resident low-mcome citizens or housing developers.

Since the law to be enforced is a state statute of general importance, the breadth of the public mterest in proper execution of the laws should also allow challenges by nonresidents. For example, im People

131. Cal. Crv. Proc. Code $\$ 1086$ (West 1955).

132. Board of Social Welfare v. County of Los Angeles, 27 Cal. 2d 98, 162 P.2d 627 (1945);

Knoff v. City and County of San Francisco, 1 Cal. App. 3d 184, 81 Cal. Rptr. 683 (Ist Dist. 1969).

133. 33 Cal. App. 3d 252, 109 Cal. Rptr. 22 (3d Dist. 1973).

134. McDonald v. Stockton Metropolitan Transit Dist., 36 Cal. App. 3d 346, 111 Cal. Rptr. 637 (3d Dist. 1973).

135. Board of Social Welfare v. County of Los Angeles, 27 Cal. 2d 98, 162 P.2d 627 (1945).

136. Id.

137. Selby Realty Co. v. City of San Buenaventura, 10 Cal. 3d 110, 118, 514 P.2d 111, 116, 109 Cal. Rptr. 799, 804 (1973).

138. Cal. Health \& SafeTy Code $\$ \$ 50001-50004$ (West 1979). 
ex rel. Younger v. El Dorado County, ${ }^{139}$ the attorney general was permitted to bring suit on behalf of all state residents in part because people throughout the State used the Lake Tahoe region. Standing should be even inore certain when a plan is challenged because it does not adequately meet specific obligations toward particular nonresidents. In fact, the specific external effects of a plan may provide an individual stake in the controversy that will accordingly reduce the amount of public interest required. The regional general welfare test used in Livermore and the input to land-use decisions permitted to nonresidents in Scott $v$. Indian $W e l l s^{140}$ reflect judicial receptiveness to this idea. Thus, nonresident low-income persons and developers should have standing under the shimg scale test. ${ }^{141}$

\section{Remedy}

In addition to seeking a writ of inandamus forcmg reformulation of the defective general plan, a plaintiff would most likely seek an injunction against zoning changes, subdivision approvals, and building permits, or agamst approval of specific projects associated with areas im which the plan requires major revision. When the sole allegation is the inadequacy of the plan, a court must consider whether these remedies, in addition to requiring reformulation of the plan, will be necessary to effectuate the legislature's imtention that "each county and city . . . adopt a comprehensive, long-terin general plan for . . . physical developinent." 142

The legislature clearly desired that each municipality adopt a sufficient plan and that, at a minimum, it serve to inform local land-use decisionınaking. Without injunctive rehef, it is unlikely that either goal can be achieved. When the sole remedy is reformulation of the plan, a city has little incentive to consider a plan seriously or promptly. In the litigation context, it is likely that interim adjustments with lasting effects would be pending while the plan is reformulated. Yet, without injunctive relief, a city could approve and implement projects while simultaneously adopting a plan that necessarily calls for their disapproval. This would make a mockery of both the plan and the planning law. ${ }^{143}$

139. S Cal. 3d 380, 487 P.2d 1193, 96 Cal. Rptr. 553 (1971).

140. 6 Cal. 3d 541, 492 P.2d 1137, 99 Cal. Rptr. 745 (1972).

141. In addition, the attorney general has the unquestioned authority to bring any civil action on behalf of the people of California. He or she may "file any civil action for the enforcement of the laws of the state or the United States Constitution, which in the absence of legislative restriction he deems necessary for the protection of public rights and interests." People ex rel. Lynch v. Superior Court, 1 Cal. 3d 910, 912, 464 P.2d 126, 127, 73 Cal. Rptr. 670, 671 (1970).

142. CAL. Gov'T CODE $\S 65300$ (West 1966).

143. The California Supreme Court has granted a hearing in a case which will consider this 


\section{G. Challenging Local Land-Use Decisions Inconsistent With the General Plan}

Under Government Code section 65860(b), standing is available to all residents and property owners for a inandainus action challenging inconsistency caused by zoning changes. ${ }^{144}$ Additionally, a ninety-day statute of limitations is stipulated. Whether the grant of standing is exclusive has yet to be determined.

When inconsistency is caused by a change in the plan, section 65860 (c) provides only that the zoning inust be inade consistent "with a reasonable time." The specific instructions of section 65860(b) apparently do not apply to this section; however, another duty is created that should be enforceable through inandainus. The definition of reasonable time and other procedural paraineters should be deternnined through general principles of mandamus and standing. ${ }^{145}$

Exclusionary zoning controversies often arise in the context of applications for variances or conditional use permits. Whether such actions are "zoning changes" within the meaning of the statute has been the focus of case law and commentary. Both have noted that although granting of such a permit may not be a "zoning change," indirect revicw of consistency inay be available through inandainus review of the decision for conformity with the terins of the ordinance. ${ }^{146}$ Mandamus and the due process requirement should provide the control necessary to avoid circuinvention of the statutory scheme.

Two forins of relief are appropriate in a successful broadside attack on a zoning ordinance under either statutory or due process approaches. First, an order compelling changes designed to bring it into accord with the general plan would be appropriate in this context. Second, an injunction prohibiting the issuance of building permits under the inconsistent zoning would be in order.

Where large portions of a city's zoning ordinance or general plan are challenged, a court might also choose to retain jurisdiction while the city reformulates the plan or zoning. Since the reformulation may not eliminate the inconsistency, the court should retain jurisdiction; it is responsible for the origmal order and is familiar with the case. It will be in the interest of both parties to have a final judicial determination that the city has conforined with the law.

It is possible that the city could amend its general plan within the

issue. Friends of "B" St. v. City of Hayward, No. SF 23774 (Cal. Sup. Ct., hearing granted, Jan. 26, 1978).

144. CaL. Gov'T Code $\S 65860(b)$ (West Supp. 1978).

145. See discussion of standing in text accoinpanying notes $131-41$ supra.

146. See Hawkins v. County of Marin, 54 Cal. App. 3d 586, 125 Cal. Rptr. 914 (1st Dist. 1976). See also Comment, supra note 109. 
housing element regulations to be consistent with the zoning under attack. ${ }^{147}$ Until this amendment, however, the due process standard developed earlier ${ }^{148}$ would bind the city to its preexisting policy decisions. Thus, pending both a decision by the city to amend either the plan or the zoning and a determination of whether the plan could be amended to ineet the substantive requirements of the regulations, issuance of building permits should be enjomed.

When inconsistency results from a change in the local general plan, the statute requires that the zoning ordimance be amended to conform with the new general plan. ${ }^{149}$ An injunction against issuance of building permits also might be granted in this situation to prevent action inconsistent with the plan, pending the required zoning adjustinent.

When the challenge is to issuance of a discretionary land-use permit rather than an entire zoning ordinance, the first remedy is to enjoin further use of the permit pending issuance of a new permit consistent with the plan. Because courts are reluctant to usurp the discretion of the local planning commission, the proper course would be to remand the permit decision to the commission for reconsideration, allowing it to issue a new permit if possible under the plan. Similarly, the remedy for subdivision inconsistency should be demial of the subdivision permit. ${ }^{150}$ The form of action, standing, and other procedural rules in this proceeding would be identical to those apphicable in mandamus actions. ${ }^{151}$

\section{CONCLUSION}

When localities adopt exclusionary zoning ordinances, they affect the supply of low- and inoderate-income housing for an entire inetropolitan area. As the lack of concern for these extramunicipal effects inherent in the local political process becoines more apparent, state

147. CAL. Gov'T CODE $\S 65361$ (West Supp. 1978) limits amendments to a general plan to three per year.

148. See text accompanying notes 110-18 supra.

149. Cal. Gov't CODE $\S 65860$ (c) (West Supp. 1978).

150. The Act also provides certam specific remedies in actions to attack subdivisions. See CAL. Gov'T CODE $\S \S 66499.32-37$ (West Supp. 1978). However, these provisions are in addition to the court's normal powers. Id. $\S 66499.33$. It is noteworthy that although land-use decisions are normally reviewed in the light of plans existing at the time of judicial review. Selby Realty Co. v. City of San Buenaventura, 10 Cal. 3d 110, 514 P.2d 111, 109 Cal. Rptr. 799 (1973), the California Supreme Court recently held that subdivision consistency would be determined in the light of the plan as it existed at the time of tentative approval of the subdivision map. Youngblood v. Board of Supervisors, 22 Cal. 3d 644, 586 P.2d 586, 150 Cal. Rptr. 242 (1978). In the context of the land-use issues involved in this Comment, the use of this rule is relatively unimportant as the substantive requirements of the housing element may be relied upon to prevent the locality from changing its plan.

151. See text accoinpanying notes $125-41$ supra. 
courts are beginning to reexamine the wisdom of the deference that they have traditionally given to local government's land-use decisions.

In Livermore, the California Supreme Court has begun to address this issue in a cautiously activist manner. The court's warniess is understandable in light of the experience of other state courts that have searclied, with uneven success, for workable nondeference standards. Before the California courts can be expected to completely abandon the principle of deference, an attractive, workable alternative must be readily available in implementable fornt.

Such an alternative is presented by the statutory and admimistrative mechanisms examined in this Comment. Like Livermore, these nreclanisms reflect a determination that decisions affecting housing supply must reflect regional and statewide concerns. The administrative agency has the competence and political responsibility to authoritatively resolve the conflict between the need for housimg and other land-use alternatives. The administrative resolution, as reflected in the lousing element regulations and the local plans promulgated pursuant to those regulations, provide standards that courts in the postLivermore era can look to in assessing local land-use decisions. The consistent utilization of these standards by the California judiciary will effectively contribute to the near-tern realization of the state's housing goals. Most importantly, under this system, the responsibility for balancing the niany competing interests involved in land-use policy will be properly reposited with the legislature and its agencies, pursuant to the institutional framework mandated by the state constitution. Each branch of state government, and the citizenry to which they are responsible, would benefit from a statewide implementation of these mechanisnis in future California land-use policy fornulation.

Edward G. Weil*

Stephen F. Ross***

* A.B. 1975, University of California, Berkeley; J.D. 1979, Boalt Hall School of Law, University of California, Berkeley; Candidate for M.C.P. 1980, Department of City and Regional Planning, University of California, Berkeley.

** A.B. 1976, University of California, Berkeley; J.D. 1979, Boalt Hall School of Law, University of California, Berkeley. 